KAMIL WABNIC

ORCID: 0000-0001-9762-3420

Uniwersytet Wrocławski

Wydział Filolgiczny, Instytut Filologii Polskiej

\title{
Znaczenie i pochodzenie frazemu „kto [...], ten się w cyrku nie śmieje”
}

\begin{abstract}
Abstrakt
$\mathrm{W}$ artykule przedstawiono analizę frazemu ze stałymi miejscami otwartymi kto [...], ten się w cyrku nie śmieje. Analizowana jednostka języka stanowi przykład konstrukcji, która rozpowszechniła się w uzusie za sprawą komunikacji zapośredniczonej komputerowo i memów internetowych. Cechy strukturalne tego frazemu wyróżniają go spośród typowych memów internetowych i sprawiają, że może być on odbierany przez użytkowników języka podobnie jak przysłowia bądź inne typy wypowiedzi o charakterze gnomicznym. Charakterystyczna jest również jakość otwartego miejsca frazemu, ponieważ wymaga wypełnienia frazą werbalną, a nie - jak w większości tego typu konstrukcji — frazą nominalną.

W artykule zaprezentowano analizę semantyczną, leksykalną i składniową frazemu oraz próby ustalenia jego pochodzenia.
\end{abstract}

Słowa kluczowe: leksykologia, frazem ze stałymi miejscami otwartymi, skrzydlate słowa, mem internetowy, rusycyzm.

\section{Wstęp}

Rozwój sieci komputerowych, a co za tym idzie - komunikacji zapośredniczonej komputerowo $\left(\mathrm{CMC}^{1}\right)$ - doprowadził do rozprzestrzenienia się $\mathrm{w}$ tekstosferze tekstów zwykle określanych mianem memów internetowych ${ }^{2}$. Memy internetowe

${ }^{1}$ Komunikacja zapośredniczona komputerowo (ang. Computer mediated communication) opierająca się przede wszystkim na asynchronicznej lub zbliżającej się do synchronii, a coraz częściej także synchronicznej, wymianie tekstów stanowi przedmiot zainteresowania medioznawców, językoznawców, jak też socjologów czy antropologów, którzy dokonują kolejnych prób kompleksowego opisu różnych zjawisk językowych i kulturowych towarzyszących intensywnemu rozwojowi tego typu komunikacji międzyludzkiej.

${ }^{2}$ Pojęcie memu internetowego rozumiem zgodnie z ujęciem tekstologicznym jako multimodalny gatunek tekstu składający się z elementów ikonograficznego oraz językowego (tak zwany image macro, por. Vickery 2014; Dynel 2016; Niekrewicz 2017; Barczewska 2020). Mem ma zwykle charak- 
za sprawą swoich wielu realizacji oraz mechanizmów powstawania i reprodukowania mają potencjał tworzenia i utrwalania innowacji językowych (funkcjonujących najpierw jako cytat, a z czasem - jako jednostki leksykalne, w tym frazeologizmy). W licznych pracach opisuje się i rejestruje innowacje powstałe w internecie lub przynajmniej utrwalone za sprawą użytkowników internetu (por. Burkacka 2015, OJ UW). Obok pojedynczych wyrazów rejestrowane są również innowacyjne frazy zawierające silniej lub słabiej utrwalone połączenia składników i spełniające definicję frazeologizmu ${ }^{3}$. Często są to dwuskładnikowe frazy nominalne ${ }^{4}$, na przykład tajemnica poliszynszyla; wujek Google, ale spotykane są także frazy werbalne lub większe części wypowiedzeń, na przykład argument jest inwalidą; taki mamy klimat; ale się nie uśmiechał; taki jest koszt demokracji (OJ UW). Na szczególną uwagę zasługują frazy werbalne, ponieważ ze względu na swoją strukturę i sposób użycia mogą one oddalać się od frazeologizmów i stawać się cytowanymi lub reprodukowanymi tekstami, a w szczególnych przypadkach - matrycami składniowymi ze stałymi miejscami otwartymi (por. Chlebda 2005: 127-129). Można rozważać je zarówno w kontekście leksykologicznym, jak i tekstologicznym, podobnie jak czyni się z paremiami. Niejako odrębny sposób ujęcia podobnych frazemów stanowią skrzydlate słowa, dla których interpretacji istotne są również źródło zaczerpnięcia frazemu oraz pragmatyka jego reprodukcji (por. Chlebda 2005, 2007, 2020). Niniejszy artykuł zawiera opis jednego $\mathrm{z}$ takich frazemów: kto [...], ten się w cyrku nie śmieje.

\section{Cel badań i metodologia}

Celem badań referowanych w niniejszym artykule było uzyskanie szczegółowego opisu frazemu o stałych miejscach otwartych kto [...], ten się $w$ cyrku nie śmieje. Wykonanie takiego opisu wymaga analizy różnych poziomów językowych tej jednostki języka:

a) analizy leksykalnej i semantycznej,

b) analizy składniowej,

c) analizy etymologicznej.

Analiza leksykalna i analiza semantyczna pozwalają ustalić znaczenie frazemu i powiązać go z jednostkami języka podobnymi pod względem znaczenia. Innowa-

ter ludyczny, groteskowy lub absurdalny; posługuje się ironią, hiperbolą lub karykaturą. Mem jako tekst jest silnie intertekstualny, co wynika z jego licznych powielań oraz modyfikacji (Zdunkiewicz-Jedynak 2016: 58-59). Pomijam zatem tutaj kulturoznawcze, memetyczne rozumienie memu jako jednostki informacji (por. Dawkins 1996; Blackmore 2004; Kamińska 2011; Kołowiecki 2012; Burkacka 2016) i koncentruję się na typie tekstu internetowego.

3 'Stosunkowo stabilne, odtwarzalne połączenie wyrazów, charakteryzujące się obrazowością, asumarycznością semantyczną i ekspresywnością’ (Nowakowska 2005: 23).

${ }^{4}$ Utrwalone frazy nominalne bardzo często stają się źródłem neofrazeologizmów. Badacze wyróżniają również szczególnie produktywne podstawy takich fraz, na przykład efekt lub rewolucja (por. Dziamska-Lenart i Fliciński 2016). 
cja ta wykorzystuje w swoim składzie leksemy, które poprzez utrwalone połączenie zyskały presuponowane znaczenie wykraczające poza sumę literalnych znaczeń tych leksemów. Innowacja korzysta przy tym z powiązań metaforycznych lub metonimicznych opartych na zjawiskach homonimii lub polisemii.

Analiza składniowa konieczna jest do opisu struktury frazemu, ponieważ stanowi on matrycę częściowo wypełnioną opartą na wypowiedzeniu złożonym. Taka analiza pozwala ustalić morfologiczny i semantyczny charakter leksemów potencjalnie wypełniających tę matrycę oraz ich związki paradygmatyczne i syntagmatyczne, a także odkryć procesy stojące za przekształceniem frazemu w matrycę składniową.

Pierwszy etap badań przedstawionych w artykule polegał na ustaleniu ogólnej struktury składniowej frazemu, drugi etap obejmował analizę składników frazemu — leksykalną i semantyczną części stale wypełnionej — oraz składniową, leksykalną i semantyczną części o otwartych miejscach. Ostatni zaś etap to analiza etymologiczna, która pozwoliła ustalić przybliżony czas utrwalenia frazemu w języku polskim, jego ewolucję oraz źródło.

Materiał badawczy stanowiły użycia frazemu uzyskane w wyszukiwarce korpusowej MoncoPL (Pęzik 2020) i różnych wyszukiwarkach internetowych (Google, Yahoo i Bing) w maju 2021 roku.

\section{Analiza składniowa struktury frazemu}

Frazem kto [...], ten się w cyrku nie śmieje stanowi matrycę składniową o częściowym wypełnieniu leksykalnym z pozostawionymi stałymi miejscami otwartymi. Jest to stan zbliżony do opisywanego przez Wojciecha Chlebdę w wypadku frazemów tworzonych od frazemów tytułopochodnych (Chlebda 2005: 128-129). Chlebda zwraca uwagę na zjawisko wariantywnej realizacji niektórych skrzydlatych słów, na przykład Rękopis znaleziony w X, Czyż nie dobija się X-ów, Dyskretny X Y-a, Ci wspaniali $X$-i na swych Y-owych Z-ach. Występują w nich otwarte miejsca (do trzech - oznaczone $X, Y$ i $Z$ ), które należy wypełnić leksykalnie składnikami nominalnymi. W wypadku analizowanego frazemu otwarte miejsce wymaga wypełnienia frazą werbalną. Jest tak, ponieważ kto [...], ten się w cyrku nie śmieje to wypowiedzenie złożone hipotaktycznie. Pierwsze wypowiedzenie składowe jest zdaniem podrzędnym podmiotowym wyszczególniającym względnym — zgodnie z klasyfikacją tradycyjną (por. Klemensiewicz 1968: 84). Funkcję wskaźników zespolenia pełni para zaimków względnych $k t o$, ten. Zdanie podrzędne zastępuje grupę podmiotu zdania nadrzędnego i określa, kto się w cyrku nie śmieje. Całe zdanie złożone jest zatem zdaniem relatywnym substytucyjnym - restryktywnym (por. Grzegorczykowa 2012: 117-121). Wypowiedzenie podrzędne jest aktualizowane przy każdej realizacji frazemu i wypełniane predykatywną frazą werbalną, która deskryptywnie określa agensa wypowiedzenia - możliwe wypełnienia tego miejsca w matrycy składniowej opisuje fragment dotyczący analizy leksykalnej i semantycznej. 
Interesujący jest fakt, że ze względu na budowę składniową i użycie wskaźnika zespolenia $k$ to, ten ${ }^{5}$ analizowany frazem upodabnia się do przysłów, z których wiele również ma formę zdań relatywnych substytucyjnych (por. Greimas 1978; Smoleń-Wawrzusiszyn 2003).

\section{Analiza składników frazemu}

Analizowana jednostka jako frazem o częściowym wypełnieniu leksykalnym zawiera zarówno stale występujące w niej wyrazy, jak i miejsca otwarte. Oba elementy wymagają odrębnego opisu, ponieważ w różny sposób decydują o całościowym znaczeniu analizowanej jednostki.

\subsection{Wyrazy stale wypełniające frazem}

Stale wypełnioną częścią frazemu jest fraza werbalna się w cyrku nie śmieje ${ }^{6}$ Jej podstawą jest zaprzeczony predykat ŚMIAĆ SIĘ oraz wyrażenie przyimkowe $w$ cyrku, które jest formą miejscownika rzeczownika CYRK. Morfologicznie są to więc dwie słowoformy, które reprezentują dwa odmienne lematy ${ }^{7}$.

\subsubsection{CYRK}

Lematowi CYRK opracowania leksykograficzne przypisują kilka znaczeń (por. ISJP 2000, SJP PWN, Słowosieć, WSJP):

a) znaczenia związane $\mathrm{z}$ rodzajem widowiska, przedsiębiorstwem zajmującym się takimi widowiskami lub miejscem tych widowisk;

b) znaczenia związane z zabawną lub absurdalną sytuacją albo czyimś nietypowym zachowaniem;

c) znaczenia związane z kolistymi budowlami starorzymskimi;

d) znaczenia dotyczące zjawisk geologicznych.

Analizowany frazem korzysta ze znaczeń a) oraz b), czyli związanych z widowiskiem i zabawną sytuacją. Ponadto znaczenia te również są ze sobą powiązane - znaczenie metaforyczne dotyczące sytuacji wyraźnie czerpie ze znaczenia a). Cyrk jako widowisko artystyczne często zaskakuje swoich widzów, budzi zachwyt, wesołość lub podziw dla umiejętności cyrkowców, opiera się czasem na absurdzie lub grotesce ostatecznie ma mieć wymiar rozrywkowy i ludyczny. W ramach konwencji artystycz-

${ }^{5}$ Częste jest również pominięcie zaimka ten.

${ }^{6} \mathrm{Z}$ frazy wyłączam zaimki ten oraz kto, które stanowią złożony wskaźnik zespolenia łączący wypełnioną oraz otwartą część frazemu.

${ }^{7} \mathrm{~W}$ tej pracy rozróżniam pojęcia lematu i leksemu. Jako lemat rozumiem formę hasłową reprezentującą wszystkie słowoformy składające się na paradygmat fleksyjny jednostki; etykietę bez powiązania ze znaczeniem. Leksem to abstrakcyjna jednostka języka, która wiąże realizujące ją słowoformy ze znaczeniem. 
nej wydarzenia cyrkowe nie są z pewnością niczym negatywnym. Znaczenia typu a) nie są zatem nacechowane emocjonalnie, ale znaczenia typu b) - już są ${ }^{8}$. Dzieje się tak, ponieważ to, co oczekiwane i pozytywne w ramach cyrkowej konwencji, jest odbierane negatywnie poza tą konwencją. Gdy użytkownicy języka dostrzegają w codziennych sytuacjach zjawiska lub zachowania przypominające widowisko cyrkowe pod względem absurdalności lub niezwykłości, wartościują je negatywnie i nazywają cyrkiem w ramach znaczenia b). Można zatem uznać, że w analizowanym frazemie dochodzi do podobnego użycia cyrku w znaczeniu b), ale z odwołaniem w warstwie literalnej do znaczenia a). Podobnie rzecz się ma w wypadku innych frazemów zawierających CYRK, które odnotowuje WSJP: cyrk na kótkach oraz nie mój cyrk, nie moje malpy ${ }^{9}$.

Literalnie w stałej części mamy do czynienia z formą miejscownika - wyrażenie przyimkowe $w$ cyrku — która składniowo pełni funkcję okolicznika miejsca. Sugeruje to użycie wyrazu CYRK w znaczeniu miejsca widowiska artystycznego lub w znaczeniu samego widowiska, ponieważ formę $w$ cyrku można również rozumieć jako podczas widowiska cyrkowego. Takie użycie nie przystaje do znaczenia b), jednakże użycie wyrazu cyrk w znaczeniu a) może poprzez swój metaforyczny charakter nadawać sytuacji opisywanej w części otwartej frazemu (zdanie podrzędne wprowadzane zaimkiem względnym $k t o$ ) miano cyrku w sensie b): 'zabawna lub absurdalna sytuacja.'

\subsection{2. ŚMIAĆ SIE}

Słowniki rejestrują kilka zbliżonych znaczeń przypisanych do lematu ŚMIAĆ SIĘ (por. ISJP 2000, SJP PWN, Słowosieć, WSJP) — najwięcej znaczeń spośród analizowanych źródeł podaje Słowosieć, bo aż sześć:

1. 'reagować na coś rozbawieniem, znamionowanym przez mimikę twarzy, wydawane odgłosy, skurcze przepony — śmiech';

2. 'naśmiewać się z kogoś lub czegoś, wyśmiewać';

3. 'lekceważyć coś, nic sobie nie robić z czegoś, nie liczyć się z czymś, mieć za nic’;

4. 'świadczyć o tym, że ktoś jest szczęśliwy lub rozbawiony’;

5. 'kpić, żartować z kogoś lub czegoś, robić coś, co może być odbierane jako złośliwość, sprawiać przykrość czymś, co jest odbierane jako drwina; robić z kogoś głupca’;

6. 'żartować, mówić o czymś żartobliwym tonem'.

Znaczenia te można pogrupować:

a) znaczenia dotyczące reakcji fizjologicznej ( 1 - dotyczy śmiechu, $4-$ dotyczy ogólnych oznak radości lub rozbawienia i stanowi znaczenie raczej metaforyczne);

${ }^{8}$ W Słowosieci znaczenia typu a) są oznaczone jako niemające nacechowania emocjonalnego, znaczenia typu b) są sklasyfikowane jako słabe negatywne (według skali: mocne negatywne, słabe negatywne, neutralne, słabe pozytywne, mocne pozytywne i niejednoznaczne) i mają przypisane emocje: złość i smutek oraz wartościowanie: krzywda i nieużyteczność (Słowosieć, o anotacji emocjonalnej w Słowosieci zob. Zaśko-Zielińska, Piasecki 2018).

${ }^{9}$ Drugi z nich pojawia się także w Wielkim słowniku frazeologicznym (Fliciński 2012) pod postacią twój cyrk, twoje małpy, jako jedyne hasło zawierające CYRK. 
b) znaczenia dotyczące zachowania lub sposobu komunikacji (2, 3, 5 i 6).

Podobnie jak w wypadku użycia wyrazu CYRK, w wypadku ŚMIAĆ SIĘ mamy prawdopodobnie do czynienia ze znaczeniem literalnym dotyczącym reakcji fizjologicznej a) - doświadczenie widowiska cyrkowego powinno wywoływać fizjologiczną reakcję radości i rozbawienia (wszak taki jest rozrywkowy, ludyczny cel cyrku). $\mathrm{W}$ analizowanym frazemie jednak agens takiej reakcji nie doświadcza - można to rozumieć literalnie, że z powodu jego doświadczeń opisywanych w części otwartej frazemu jest w ogóle niezdolny do radości, lecz bardziej odpowiednia wydaje się interpretacja, w której przenosi się znaczenie literalne na znaczenie metaforyczne wyrazu CYRK. Agens jest tak dotknięty doświadczeniem licznych absurdalnych sytuacji, że nie chce lub nie potrafi już traktować ich lekceważąco, żartobliwie lub z kpiną. Interpretowanie wyrazu CYRK zgodnie ze znaczeniem b) również przenosi wyraz ŚMIAĆ SIĘ ze znaczenia a) do metaforycznego b): 'zachowanie lub sposób komunikacji'.

Analizowany frazem ma zatem cechy wspólne z przysłowiami, gdyż zarówno one, jak i ten frazem są jednostkami konotowanymi, czyli przenoszą element znaczony z jednego zakresu semantycznego na inny (por. Greimas 1978: 310-311). $\mathrm{W}$ wypadku analizowanej jednostki zjawisko to zachodzi w obrębie różnych znaczeń reprezentowanych lematami CYRK i ŚMIAĆ SIĘ.

\subsection{Wyrazy wypełniające miejsca otwarte}

Wypowiedzenie składowe wprowadzane zaimkiem względnym kto nie ma stałego wypełnienia. Użytkownicy języka uzupełniają tę część frazami werbalnymi budowanymi zwykle przez dwa składniki: predykat i dopełnienie lub okolicznik — czasem składnik nominalny ma rozwinięcie, wówczas liczba składników rośnie do co najmniej trzech. Predykaty pojawiają się wariantywnie w czasie przeszłym lub teraźniejszym.

Wyszukiwarka Monco zaindeksowała około $125^{10}$ wystąpień analizowanego frazemu. Analiza kontekstów występowania frazemu pozwala wyznaczyć kilka głównych pól semantycznych, zostały one opisane w dalszej części tego artykułu.

\subsubsection{Frazy z predykatami ŻYĆ, MIESZKAĆ, URODZIĆ SIĘ}

Jedną z dominujących grup semantycznych stanowią wypełnienia miejsc otwartych frazami dotyczącymi miejsca zamieszkania lub codziennej egzystencji agensa. Najwięcej wystąpień zawiera w sobie czasownik MIESZKAĆ, rzadziej ŻYĆ lub URODZIĆ SIĘ. Czasowniki te zwykle są określane okolicznikami miejsca (MIESZKAĆ/ ŻYĆ/URODZIĆ SIĘ $-w \mathrm{~N}_{6}$ ) odnoszącymi się do Polski lub konkretnych miejsc w Polsce, rzadziej pojawiają się inne warianty (na przykład typ budynku [3]). Użycia z czasownikami ŻYĆ i URODZIĆ SIĘ dotyczą tylko wariantu [1].

${ }^{10}$ Ich liczba może się wahać zależnie od zapytania. Zapytanie $w$ cyrk ${ }^{* *}$ nie śmiać ${ }^{* *}$ się z dopuszczoną różną kolejnością składników oraz nieciągłością frazy do dwóch miejsc daje 127 wyników. Stan na 19 maja 2021. 
[1] Kto mieszka w Polsce, ten się w cyrku nie śmieje $(14)^{11}$;

[2] Kto w Lublinie mieszka, ten się w cyrku nie śmieje (2 - tylko MIESZKAĆ);

[3] Kto mieszka w bloku, ten się w cyrku nie śmieje (1).

Z czasownikiem MIESZKAĆ występuje też połączenie z okolicznikiem akcesoryjnym $z$ kobieta (MIESZKAĆ - praep $\mathrm{N}_{\mathrm{co}}$ ):

[4] Kto mieszkał z kobietą, ten się w cyrku nie śmieje (3).

Potencjalnie ten schemat może zostać uzupełniony innymi wariantami takiego okolicznika (ilustracja 3), jednak nie występują one w MoncoPL. Powyższe schematy reprezentowane są w memach internetowych (ilustracje 1 i 3 ) oraz wykorzystywane w tekstach publicystycznych (ilustracja 2) i hasłach politycznych (ilustracja 4).

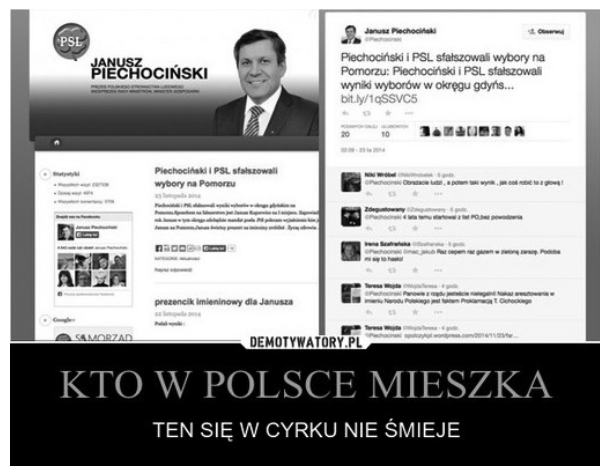

Ilustracja 1. Kto w Polsce mieszka, ten się w cyrku nie śmieje

Źródło: https://demotywatory.pl/4421150/KTO-W-POLSCE-MIESZKA, data publikacji: 23 listopada 2014.

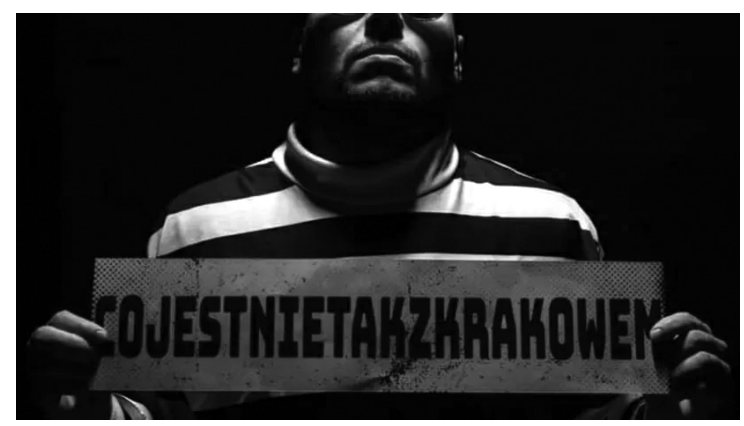

Ilustracja 2. Kto mieszka w Krakowie, ten w cyrku się nie śmieje jako tytuł artykułu

Źródło: https://wiadomosci.radiozet.pl/Popoludniowy-Gosc-Radia-ZET/Aktywista-autor-profilu-Co-jest-nie-tak-z-Krakowem-gosciem-Agnieszki-Kolodziejskiej, data publikacji: 29 kwietnia 2021.

${ }^{11}$ Wszystkie cytowane w ten sposób wypełnienia frazemu pochodzą z wyszukiwarki MoncoPL. Cytowane przykłady sprowadzane są do najpopularniejszego wariantu w swojej grupie, do jednego wariantu zaliczane są realizacje $\mathrm{z}$ wymienionymi wcześniej predykatami i składnikami nominalnymi reprezentującymi jeden paradygmat semantyczny (na przykład nazwy miast) oraz o różnym szyku w części otwartej oraz stale uzupełnionej. W nawiasie po przykładzie podaję liczbę wystąpień w wyszukiwarce MoncoPL oraz inne kluczowe informacje. 


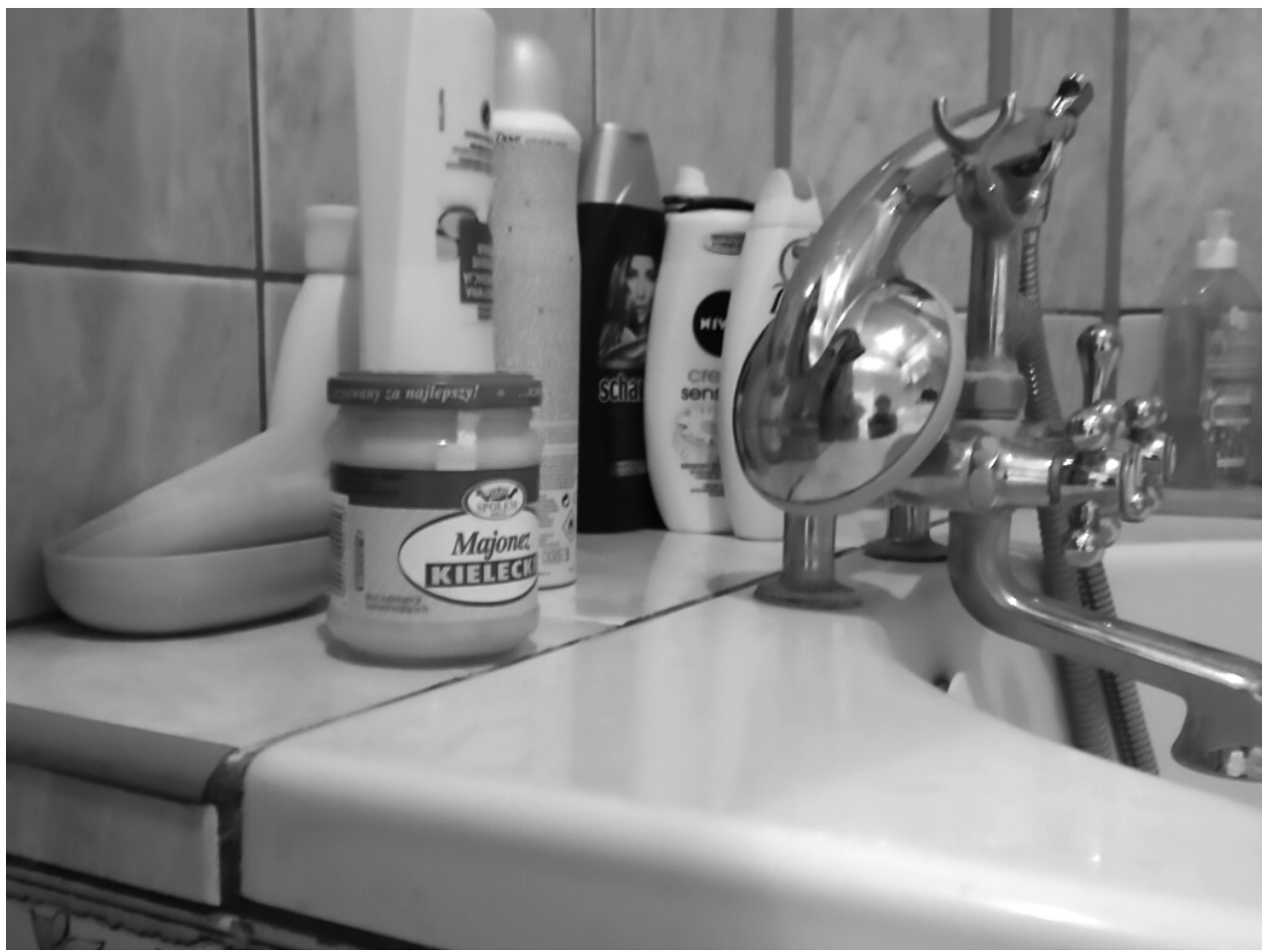

Ilustracja 3. Kto mieszka ze scyzorykiem, ten się w cyrku nie śmieje

Źródło: https://www.wykop.pl/wpis/45788379/kto-mieszka-ze-scyzorykiem-ten-sie-w-cyrku-nie-smi/, data publikacji: 1 grudnia 2019.

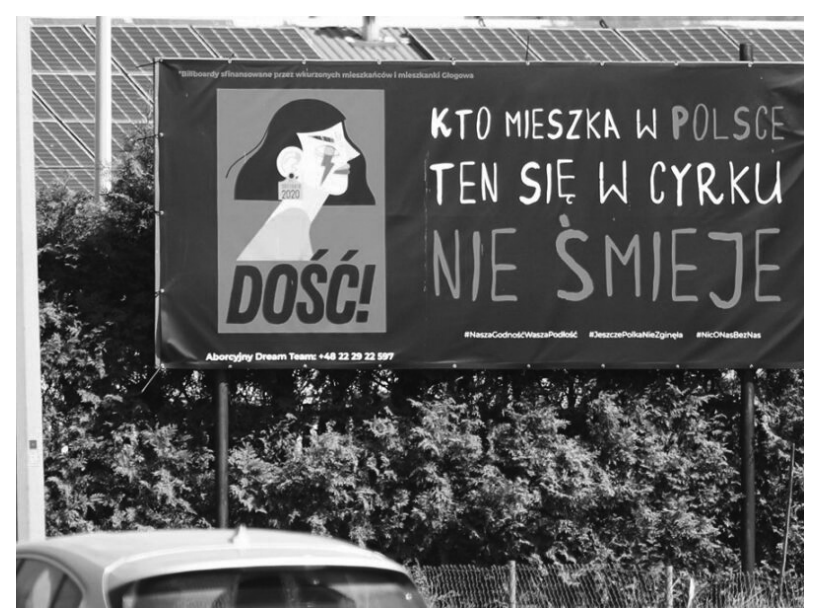

Ilustracja 4. Kto mieszka w Polsce, ten się w cyrku nie śmieje na plakacie w Głogowie

Źródło: https://myglogow.pl/baner-strajku-kobiet-kto-mieszka-w-polsce-ten-sie-w-cyrku-nie-smieje/, data publikacji: 27 kwietnia 2014. 


\subsubsection{Frazy z predykatem PRACOWAĆ}

Powtarzalna jest również realizacja frazemu z wypełnieniem frazą werbalną z predykatem PRACOWAĆ. Tutaj również pojawiają się wariantywne realizacje z okolicznikiem miejsca określającym miejsce pracy lub sektor działalności (PRACOWAĆ $-w \mathrm{~N}_{6}$; [5]) oraz z okolicznikiem akcesoryjnym (PRACOWAĆ - praep $\left.\mathrm{N}_{\mathrm{co}} ;[6]\right)$ :

[5] Kto pracował w szpitalu, ten się w cyrku nie śmieje (4);

[6] Kto pracował $\mathrm{z}$ klientami, ten się $\mathrm{w}$ cyrku nie śmieje (2).

Pojawiają się również warianty z rozszerzoną frazą nominalną w obrębie okolicznika:

[7] Kto pracował w polskim szpitalu, ten się w cyrku nie śmieje (1); lub z dodatkowym okolicznikiem (jako $+\mathrm{N}_{1}$ ):

[8] Kto pracował w Polsce jako lekarz, ten się w cyrku nie śmieje (1).

$\mathrm{W}$ internecie pojawiają się również liczne memy wykorzystujące ten schemat realizacji frazemu (ilustracje $5 \mathrm{i}$ 6), a sklep internetowy Niespodziewajka.com sprzedaje koszulki z napisem zawierającym analizowany frazem (ilustracja 7).

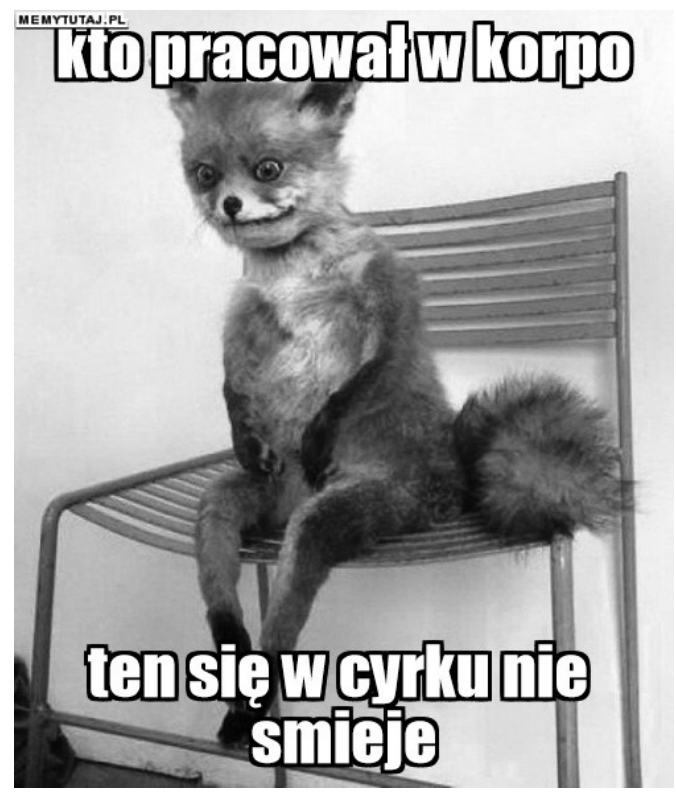

Ilustracja 5. Kto pracowat w korpo, ten się w cyrku nie śmieje

Źródło: https://memytutaj.pl/uploads/2018/03/23/5ab4f1eacb992.jpg, data publikacji: 23 marca 2018. 


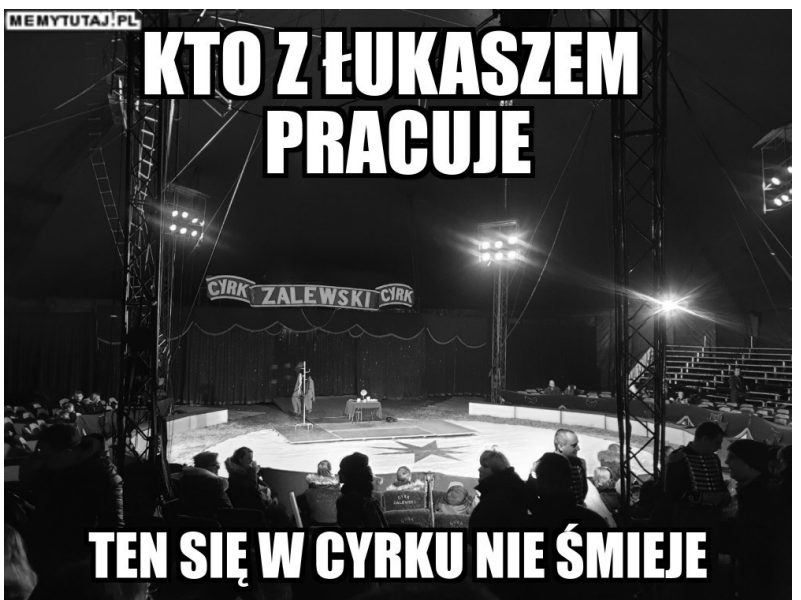

Ilustracja 6. Kto $z$ Łukaszem pracuje, ten się w cyrku nie śmieje

Źródło: http://memytutaj.pl/kto-z-lukaszem-pracuje-ten-sie-w-cyrku-nie-smieje-477705, data publikacji: 24 lutego 2019.

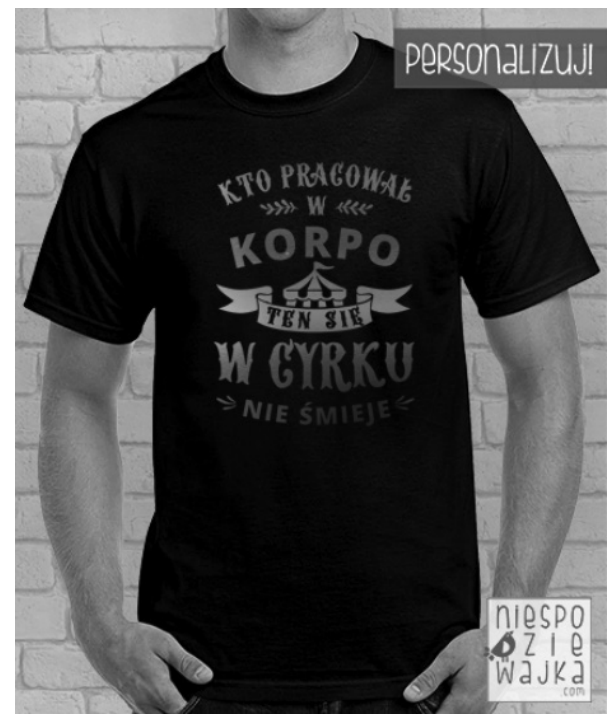

Ilustracja 7. Koszulka $\mathrm{z}$ napisem Kto pracował w korpo, ten się w cyrku nie śmieje

Źródło: https://niespodziewajka.com/koszulka-kto-pracowal-w-ten-sie-w-cyrku-nie-smieje-korpo-banku-szkole-firmie-x-p-2705.html.

\subsubsection{Frazy zawierające odniesienie do pola semantycznego WOJSKO}

Wiele realizacji frazemu, a w szczególności te najstarsze, zawiera odniesienia do służby w wojsku. W wyszukiwarce MoncoPL znajduje się tylko jedno takie użycie 
[9], lecz często występuje ono w memach $\mathrm{w}$ różnych wariantach z czasownikami BYĆ lub SŁUŻYĆ (ilustracje 8 i 9). Z formalnego punktu widzenia użycia te nie różnią się znacznie od tych wykorzystujących czasownik PRACOWAĆ lub pole semantyczne MIESZKAĆ, a wystąpienia czasowników BYĆ i SŁUŻYĆ wynika z kolokacyjności rzeczownika WOJSKO.

[9] Ten, kto był w wojsku, w cyrku się nie śmieje (1).

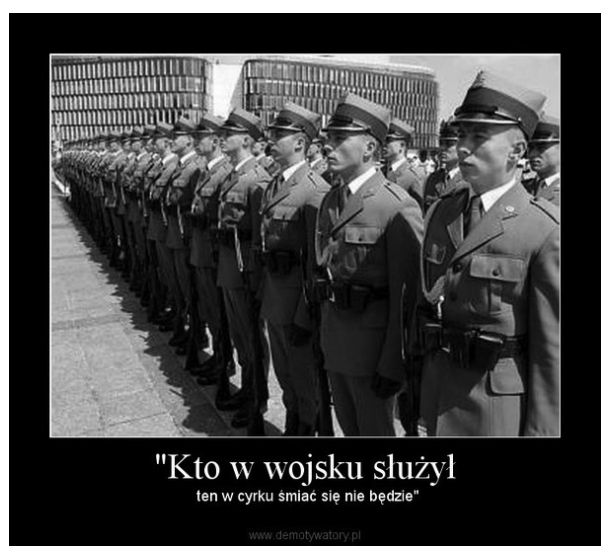

Ilustracja 8. Kto w wojsku stużył, ten w cyrku śmiać się nie będzie

Źródło: https://demotywatory.pl/1467901/Kto-w-wojsku-sluzyl, data publikacji: 25 kwietnia 2010.

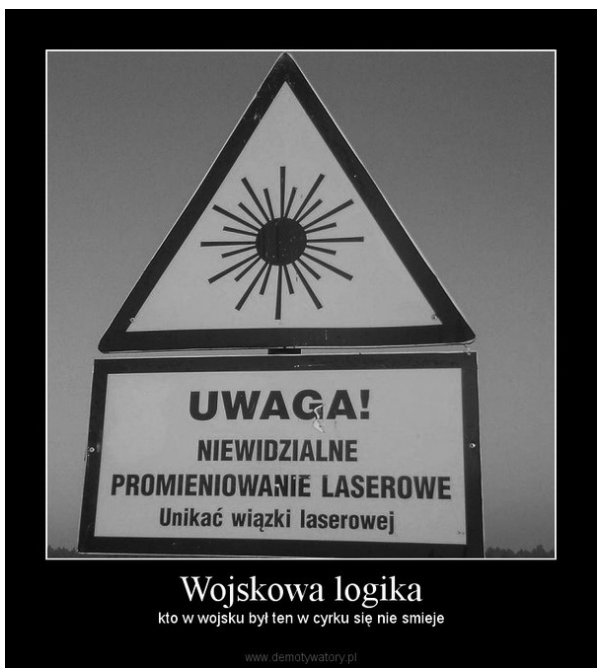

Ilustracja 9. Kto $w$ wojsku był, ten się w cyrku nie śmieje

Źródło: https://demotywatory.pl/370698/Wojskowa-logika, data publikacji: 5 listopada 2009.

Na uwagę zasługują jeszcze dwie kwestie związane z takim uzupełnieniem frazemu: ich poświadczenie w najstarszych analizowanych tekstach oraz sam fakt występo- 
wania takich kontekstów. W obecnie publikowanych tekstach warianty odnoszące się do służby wojskowej nie wydają się szczególnie częste, ale około 2010 roku, gdy frazem zaczął być popularyzowany przez memy, były to jedyne konteksty jego występowania. Prawdopodobnie wynika to $\mathrm{z}$ faktu, że była to pierwotna wersja tego frazemu, jednak na gruncie języka polskiego brakowało bodźca do wzrostu jej frekwencji, ponieważ od 2009 roku Wojsko Polskie nie przyjmowało nowych rekrutów w ramach zasadniczej służby wojskowej. Doświadczenie służby wojskowej przestawało więc być udziałem młodych dorosłych — grupy aktywnie reprodukującej podobne memy internetowe.

W tekstach innych niż memy również można znaleźć wczesne użycia analizowanego frazemu odnoszące się do służby wojskowej — w artykule $\mathrm{z}$ „Newsweeka” z 2002 roku [10] oraz w artykule z "Tygodnika Powszechnego" z 2011 roku [11]. Oba przykłady zawierają miejscownik $w$ armii lub $w$ wojsku oraz wskazują na rosyjskojęzyczne pochodzenie tego frazemu (por. 4. Pochodzenie frazemu).

[10] Na razie większość rodziców zapewnia, że zrobi wszystko, by ich syn nie poszedł do wojska. Rokrocznie setki tysięcy młodych ludzi wynosi z armii [rosyjskiej] koszmarne wspomnienia. Pytani o nie, machają ręką i podsumowują: kto był w wojsku, ten w cyrku się nie śmieje.

[11] Białoruś nigdy nie była szczególnie wesołym barakiem. Po wyborach jest tu jeszcze bardziej markotno. „Kto był w armii, ten nie śmieje się w cyrku” — mówiono w Związku Radzieckim. Jeśli rzeczywistość staje się absurdem i parodią samej siebie, żarty przestają bawić.

\subsubsection{Inne wypełnienia}

Oprócz najczęstszych omówionych wcześniej wariantów frazemu w internecie pojawiają się różne akcydentalne wypełnienia. Wykorzystują one również obok fraz z okolicznikami frazy werbalne z predykatami konotującymi dopełnienia [12-14], frazy zawierające oprócz predykatu kilka składników lub grup [15 i 16], orzeczenie słowno-imienne [17] lub dodatkowe zdanie podrzędne [18].

[12] Kto posiedzenia KRS ogląda, ten się w cyrku nie śmieje;

[13] Kto oglądał obronę Lecha jesienią, ten w cyrku się nie śmieje;

[14] Kto korzysta z leasingów, ten się w cyrku nie śmieje;

[15] Kto przeżył pożar w wieżowcu, w cyrku się nie śmieje;

[16] Kto segreguje śmieci w bloku spółdzielni mieszkaniowej, ten w cyrku się nie śmieje;

[17] Kto jest kierowcą, ten w cyrku się nie śmieje;

[18] Kto obserwuje to, co dziś wyczyniają analitycy finansowi i prezes NBP, ten się w cyrku nie śmieje.

Liczne warianty dowodzą, że użytkownicy internetu oswoili się z frazemem i zaadaptowali go jako matrycę składniową o bardzo szerokim zastosowaniu, która 
może być wypełniana treścią odnoszącą się do wielu różnych dziedzin życia. Przydaje to jej cech zbieżnych $\mathrm{z}$ memami internetowymi i niewątpliwie przyczynia się również do jej popularnego użycia jako części składowej memów.

\section{Pochodzenie frazemu}

Żadne przeanalizowane opracowania naukowe nie rejestrują tego frazemu. Jego realizacje są jedynie obecne w tekstach i korpusach, więc brakuje wiarygodnych źródeł wskazujących jego pochodzenie. Zgodnie z informacjami z artykułów w „Newsweeku” oraz „Tygodniku Powszechnym” można jedynie uznać, że frazem jest pożyczką z języka rosyjskiego.

Multiwyszukiwarka Academic.ru przeszukująca rosyjskojęzyczne słowniki i encyklopedie nie daje wyników zawierających szukany frazem w języku rosyjskim. W Narodowym Korpusie Języka Rosyjskiego (NKJR) można jednak znaleźć realizacje badanego frazemu. W NKJR w korpusie głównym znajduje się jedno wystąpienie frazemu z książki z 2000 roku [19], dziewięć wystąpień (najstarsze z 2002 ro$\mathrm{ku}$ ) w subkorpusie prasowym $\mathrm{z}$ różnym wypełnieniem [19-22], jedno wystąpienie w subkorpusie mówionym (słowa dziennikarza z 2006 roku) [19] oraz jedno wystąpienie w korpusie akcentologicznym (fragment utworu z 2011 roku zaklasyfikowanego przez twórców korpusu jako poezja naiwna) [23]. Użycia frazemu w języku rosyjskim są zatem starsze od tych znalezionych w języku polskim i mają nieco szerszą dystrybucję (w NKJP nie występują wcale), ale charakteryzują się podobną budową oraz również częściową otwartością. Ponadto rosyjski frazem jest także wykorzystywany w memach internetowych ${ }^{12}$.

[19] Кто в армии служил, тот в цирке не смеется (Kto służył w wojsku, ten się w cyrku nie śmieje $\left.{ }^{13}-7\right)$;

[20] Кто в Думе был, тот в цирке не смеется (Kto był w Dumie, ten się w cyrku nie śmieje -2$)$;

[21] Кто в Крымске жил, тот в цирке не смеется (Kto mieszkał w Krymsku, ten się w cyrku nie śmieje - 1);

[22] Кто работал на выборах, тот в цирке не смеется (Kto pracował przy wyborach, ten się w cyrku nie śmieje -1$)$;

[23] Везде есть миражи, - (Wszędzie są miraże, -)

Не плюй в проём колодца! - (Nie pluj do studni!)

Кто в армии служил, - (Kto w armii służył,)

Тот в цирке - не смеётся! - (Ten w cyrku — się nie śmieje!).

12 Zob. wyniki wyszukiwania тот в циирке не смеется w Google Grafika: https://bit.ly/3jA1m4k.

13 Tłumaczenie własne przykładów z języka rosyjskiego - K.W. 


\section{Wnioski}

Frazem kto [...], ten się w cyrku nie śmieje najprawdopodobniej jest pożyczką z języka rosyjskiego. Trudności w ustaleniu czasu i źródła pochodzenia wynikają z faktu, że realizacje frazemu funkcjonują przede wszystkim w potocznej odmianie języka i trudno dotrzeć do jego poświadczeń w innych odmianach, które zwykle są lepiej utrwalone w opracowaniach i korpusach. Różnorodne użycia tej jednostki obecne w NKJR (przy ich braku w NKJP) świadczą o większym utrwaleniu frazemu w języku rosyjskim, teksty publicystyczne również wskazują na rosyjskie źródło, a innych wskazań brak. Prawdopodobnie frazem trafił do polszczyzny za sprawą militarnych kontaktów polskich i radzieckich żołnierzy w czasach PRL, ponieważ podstawowy wariant frazemu dotyczy służby wojskowej. Frazem z czasów PRL dotrwał w mówionej odmianie polszczyzny do doby komunikacji zapośredniczonej komputerowo, gdzie został utrwalony w memach.

Frazem ma liczne warianty realizacji różniące się wypełnieniem miejsc otwartych. Najliczniejszym w języku rosyjskim oraz najstarszym w języku polskim jest wariant: kto służył w wojsku, ten się w cyrku nie śmieje i pod tą postacią frazem został zapożyczony, jednakże w obu językach ma on cechy matrycy składniowej z miejscami otwartymi.

Na gruncie języka polskiego frazem powoli zwiększał frekwencję swoich realizacji do momentu, aż w pełni odblokował otwarte miejsca, co zaowocowało licznymi wariantami realizacji. Część wariantów wykorzystuje oryginalny schemat frazy otwartej z okolicznikiem $\left(\mathrm{V}+\right.$ praep $\left.\mathrm{N}_{\mathrm{co}}\right)$, jednak pojawiają się również realizacje wykraczające poza niego.

$\mathrm{W}$ warstwie semantycznej realizacje frazemu wyrażają negatywne emocje nadawcy, które ten przejawia względem zjawisk i sytuacji (miejsce pracy, sytuacja polityczna i gospodarcza, indywidualne doświadczenia) opisywanych w części otwartej frazemu. Negatywny wydźwięk osiągany jest przede wszystkim poprzez nawiązanie do leksemu CYRK w metaforycznym znaczeniu absurdalnej lub nietypowej sytuacji. Ponadto użycie frazemu jako części składowej memów internetowych nadaje mu także znaczenie ludyczne.

Niewątpliwie do pełnej adaptacji oraz upowszechnienia frazemu przyczyniło się jego wykorzystanie w memach internetowych. Widoczna jest tutaj zdolność tego gatunku tekstu do skokowego zwiększania frekwencji innowacji językowych. Ostatecznie frazem zaczął przenikać z języka internautów do dyskursu politycznego, w którym stał się hasłem politycznym umieszczanym na plakatach (ilustracja 4) oraz transparentach (ilustracja 10). 


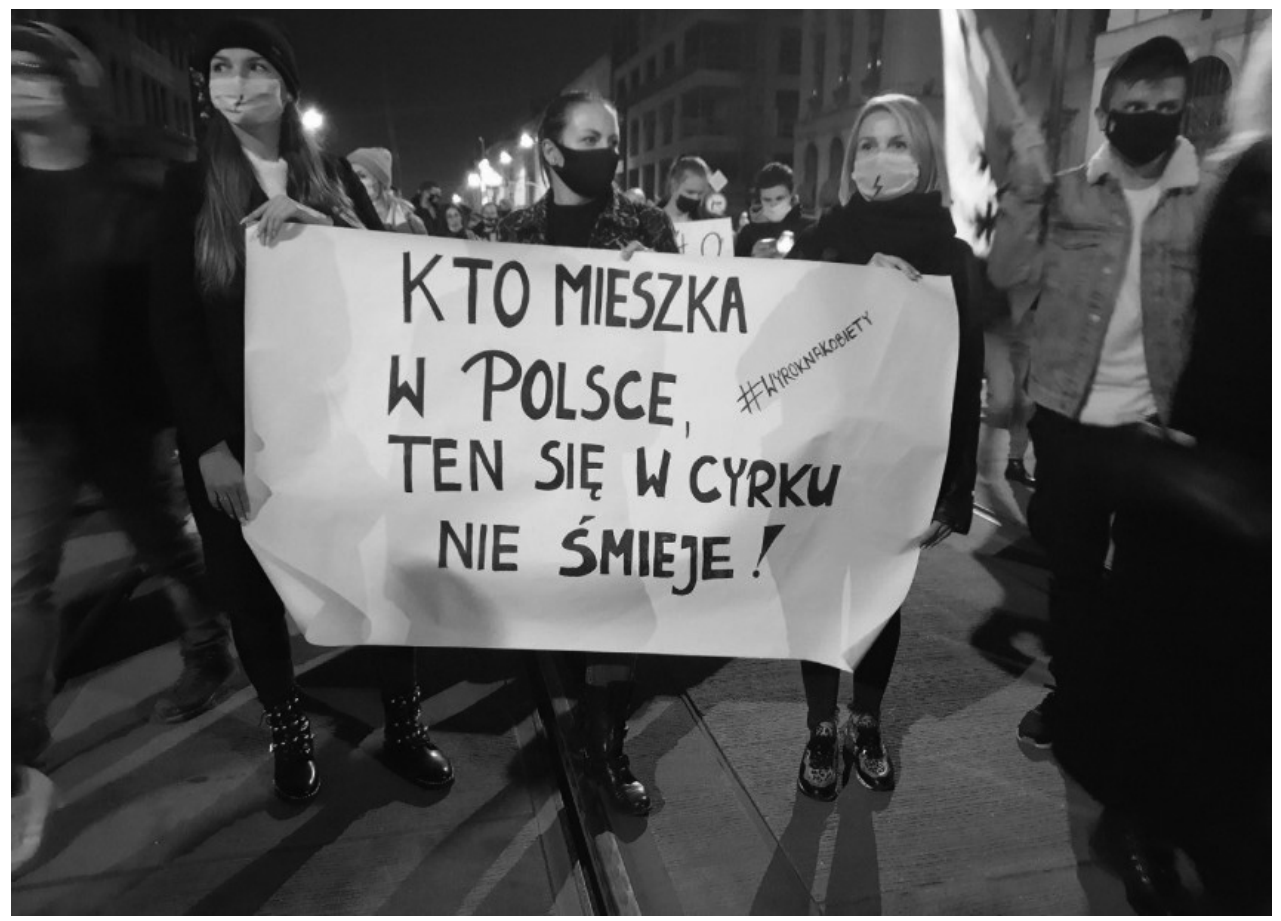

Ilustracja 10. Kto mieszka w Polsce, ten się w cyrku nie śmieje na transparencie podczas protestu kobiet w Katowicach w październiku 2020

Źródło: https://katowice.naszemiasto.pl/jarek-pierunie-uostow-frele-protest-kobiet-w-katowicach/ga/ c1-7962083/zd/57291947, data publikacji: 26 października 2020.

\section{Bibliografia}

Barczewska S. (2020): Conceptual Blends Across Image Macro Genres, „Studies in Logic, Grammar and Rhetoric" 61, nr 1, s. 7-30.

Blackmore S. (2004): Maszyna memowa, przeł. N. Radomski, Poznań.

Burkacka I. (2015): Dlaczego pieseł $i$ koteł sa lepsze od psa i kota, a nieogar jest nie halo? Uwagi o nowszych neologizmach występujacych w słownictwie młodzieżowym, [w:] Odkrywanie słowa historia i wspótczesność, red. U. Sokólska, Białystok, s. 395-408, http://hdl.handle.net/11320/9847 (dostęp: 1.06.2021).

Burkacka I. (2016): Intertekstualność współczesnej komunikacji. Memy a teksty kultury, „Poznańskie Spotkania Językoznawcze", nr 32, s. 75-91, DOI: https://doi.org/10.14746/psj.2016.32.6.

Chlebda W. (2005): Szkice o skrzydlatych słowach. Interpretacje lingwistyczne, Opole.

Chlebda W. (2007): „Ramka pragmatyczna” w procesie weryfikowania i tworzenia słownikowych definicji frazeologizmów, [w:] Język. Człowiek. Dyskurs, red. M. Hordy et al., Szczecin, s. 185-195.

Chlebda W. (2020): Reprodukowalność, reprodukcja, reprodukty, [w:] Frazeologia a reprodukowalność $w$ teorii i w praktyce komunikacyjnej. Problemy - metody analizy — opis, red. W. Chlebda, J. Taras, Białystok, s. 27-50, http://hdl.handle.net/11320/10028 (dostęp: 1.06.2021).

Dawkins R. (1996): Samolubny gen, przeł. M. Skoneczny, Warszawa. 
Dynel M. (2016): „I Has Seen Image Macros!” Advice Animal Memes as Visual-Verbal Jokes, „International Journal of Communication", nr 10, s. 660-688, https://ijoc.org/index.php/ijoc/article/viewFile/4101/1556 (dostęp: 1.06.2021).

Dziamska-Lenart G., Fliciński P. (2016): Nowa frazeologia publicystyczna, „Poznańskie Spotkania Językoznawcze", nr 31, s. 11-25.

Fliciński P. (2012): Wielki słownik frazeologiczny, Poznań.

Greimas A.J. (1978): Przysłowia i porzekadła, przeł. J. Arnold, „Pamiętnik Literacki” t. 69, nr 4, s. 309314, https://bazhum.muzhp.pl/czasopismo/8/?idno=11085 (dostęp: 1.06.2021).

Grzegorczykowa R. (2012): Wykłady z polskiej składni, Warszawa.

ISJP (2000): Inny słownik języka polskiego, red. M. Bańko, Warszawa.

Kamińska M. (2011): Niecne memy. Dwanaście wykładów o kulturze Internetu, Poznań.

Klemensiewicz Z. (1968): Zarys składni polskiej, Warszawa.

Kołowiecki W. (2012): Memy internetowe, jako nowy język internetu, „Kultura i Historia”, nr 21, http:// www.kulturaihistoria.umcs.lublin.pl/archives/3637 (dostęp: 1.06.2021).

NKJP (2010): Narodowy Korpus Języka Polskiego, http://www.nkjp.uni.lodz.pl (dostęp: 1.06.2021).

NKJR: Narodowy Korpus Języka Rosyjskiego, https://ruscorpora.ru/ (dostęp: 1.06.2021).

Niekrewicz A. (2017): Memetyczne związki wyrazowe w najnowszej polszczyźnie, „Prace Filologiczne”, t. 71, s. 225-235.

Nowakowska A. (2005): Świat roślin w polskiej frazeologii, Wrocław.

OJ UW: Obserwatorium Językowe Uniwersytetu Warszawskiego, red. K. Kłosińska et al., https://nowe wyrazy.uw.edu.pl (dostęp: 1.06.2021).

Pęzik P. (2020): Budowa i zastosowania korpusu monitorujacego MoncoPL, „Forum Lingwistyczne”, nr 7, s. 133-150.

NKJP (2012): Narodowy Korpus Języka Polskiego, red. A. Przepiórkowski et al., Warszawa, http:// nkjp.pl/settings/papers/NKJP_ksiazka.pdf (dostęp: 1.06.2021).

SJP PWN: Słownik języka polskiego PWN, https://sjp.pwn.pl/ (dostęp: 1.06.2021).

Słowosieć: http://plwordnet.pwr.wroc.pl/wordnet/ (dostęp: 1.06.2021).

Smoleń-Wawrzusiszyn M. (2003): O semantycznej ekwiwalencji przystów, „Roczniki Humanistyczne" t. 51, z. 6, s. 187-198, http://ojs.tnkul.pl/index.php/rh/article/download/4868/4762/ (dostęp: 1.06.2021).

Vickery J.R. (2014): The curious case of Confession Bear: the reappropriation of online macro-image memes, „Information, Communication \& Society”, t. 17, nr 3.

WSJP: Wielki słownik języka polskiego, https://wsjp.pl/ (dostęp: 1.06.2021).

Zaśko-Zielińska M., Piasecki M. (2018): Towards Emotive Annotation in plWordNet 4.0, [w:] Proceedings of the 9th Global Wordnet Conference, Singapore, s. 153-162, https://www.aclweb.org/anthology/2018.gwc-1.18.pdf (dostęp: 1.06.2021).

Zdunkiewicz-Jedynak D. (2016): Intertekstualność wspótczesnej komunikacji internetowej. Intertekstualne odwołania wewnątrzgatunkowe w memach, „Poznańskie Spotkania Językoznawcze”, nr 32, s. 57-73.

\section{Cytowany materiał badawczy}

[10] http://niniwa22.cba.pl/apokalipsa_poborowego.htm

[11] https://www.tygodnikpowszechny.pl/humor-wisielca-140525

\section{Ilustracje}

Ilustracja 1. https://demotywatory.pl/4421150/KTO-W-POLSCE-MIESZKA, 23 listopada 2014.

Ilustracja 2. https://wiadomosci.radiozet.pl/Popoludniowy-Gosc-Radia-ZET/Aktywista-autor-profilu-Co-jest-nie-tak-z-Krakowem-gosciem-Agnieszki-Kolodziejskiej, 29 kwietnia 2021. 
Ilustracja 3. https://www.wykop.pl/wpis/45788379/kto-mieszka-ze-scyzorykiem-ten-sie-w-cyrku-niesmi/, 1 grudnia 2019.

Ilustracja 4. https://myglogow.pl/baner-strajku-kobiet-kto-mieszka-w-polsce-ten-sie-w-cyrku-niesmieje/, 27 kwietnia 2014.

Ilustracja 5. https://memytutaj.pl/uploads/2018/03/23/5ab4f1 eacb992.jpg, 23 marca 2018.

Ilustracja 6. http://memytutaj.pl/kto-z-lukaszem-pracuje-ten-sie-w-cyrku-nie-smieje-477705, 24 lutego 2019.

Ilustracja 7. https://niespodziewajka.com/koszulka-kto-pracowal-w-ten-sie-w-cyrku-nie-smieje-korpo-banku-szkole-firmie-x-p-2705.html.

Ilustracja 8. https://demotywatory.pl/1467901/Kto-w-wojsku-sluzyl, 25 kwietnia 2010.

Ilustracja 9. https://demotywatory.pl/370698/Wojskowa-logika, 5 listopada 2009.

Ilustracja 10. https://katowice.naszemiasto.pl/jarek-pierunie-uostow-frele-protest-kobiet-w-katowicach/ga/c1-7962083/zd/57291947, 26 października 2020.

\section{"Kto [...], ten się w cyrku nie śmieje" (Who [...] doesn't laugh in the circus]: The meaning and origin of the phraseme}

\section{Summary}

The aim of the article is to present an analysis of the open-slot phraseme "kto [...], ten się w cyrku nie śmieje" (Who [...] doesn't laugh in the circus). The examined phraseme is an example of a construction that has gained popularity because of computer-mediated communication and internet memes. Structural features distinguish this phraseme from other, more typical internet memes. The analysed phraseme is more similar to proverbs or other types of gnomic expressions. The quality of open slots in the phraseme is also highly distinctive because the open slots require a verbal phrase in contradistinction to other phrasemes, which usually require a noun phrase. The article includes a semantic, lexical and syntactic analysis of this phraseme, as well as an attempt to determine its origin.

Keywords: lexicology, phraseme with open slots, culture idioms (winged words), internet meme, russicism. 